\title{
Evaluasi Pembelajaran Penjasorkes SMP Negeri di Kecamatan Ampelgading Kabupaten Malang
}

\author{
Faisal Kusuma Hadi \\ Prodi Pendidikan Olahraga, Universitas Muhammadiyah Jember \\ Email: faisalkusumahadi@ummuhjember.ac.id
}

\begin{abstract}
ABSTRAK
Penelitian ini bertujuan untuk mengetahui tingkat keberhasilan pembelajaran Pendidikan Jasmani, Olahraga dan Kesehatan (Penjasorkes) di SMP Negeri se-Ampelgading Malang serta menghasilkan rekomendasi bagi para pengambil keputusan untuk menindaklanjuti program pembelajaran yang telah berjalan. Model evaluasi yang digunakan dalam penelitian ini adalah model evaluasi CIPP dengan menggunakan teknik analisis statistik deskriptif dengan persentase. Teknik ini digunakan untuk menganalisis data yang diperoleh dari hasil penyebaran angket, dan menggunakan model yang dikembangkan oleh Daniel Stufflebeam (1967), yakni (1) context, (2) input, (3) process, dan (4) product atau yang disebut dengan CIPP. Data dikumpulkan dari hasil observasi, wawancara, angket, studi dokumentasi. Hasil penelitian ini menunjukkan bahwa variabel keseluruhan SMPN 1 Ampelgading memperoleh persentase 70\% dengan kriteria baik, SMPN 2 Ampelgading memperoleh 76\% dengan kriteria baik, SMPN 3 Ampelgading memperoleh 73\% dengan kriteria baik, SMPN 4 Ampelgading memperoleh 64\% dengan kriteria baik, SMPN 5 Ampelgading memperoleh $62 \%$ dengan kriteria baik. Berdasarkan hasil data tersebut, maka dapat disimpulkan bahwa secara keseluruhan pembelajaran pendidikan seluruh SMP Negeri di Kecamatan Ampelgading Kabupaten Malang berada pada kriteria baik. Rekomendasi berdasarkan hasil penelitian ini adalah melanjutkan program pembelajaran, akan tetapi disertai dengan revisi pada beberapa variabel.
\end{abstract}

Kata kunci: Evaluasi Pembelajaran, Pendidikan Jasmani, Olahraga dan Kesehatan , CIPP

\section{PENDAHULUAN}

Pendidikan merupakan salah satu faktor penting untuk mewujudkan cita-cita dan program pembangunan nasional secara menyeluruh. Untuk mewujudkan hal tersebut, tentu harus didukung oleh beberapa unsur sumber daya pendidikan. Salah satu unsur penting yang dapat memberikan kontribusi yang signifikan untuk mewujudkan tujuan pendidikan nasional yaitu kurikulum. Kurikulum sebagaimana yang dijelaskan dalam pasal 1 ayat 19 Undang-undang Nomor 20 Tahun 2003 merupakan suatu perangkat rencana dan pengaturan mengenai tujuan, isi, dan bahan pelajaran serta cara yang digunakan sebagai pedoman penyelenggaraan kegiatan pembelajaran untuk mencapai tujuan pendidikan tertentu.

Salah satu pembelajaran yang merupakan bagian integral dalam Sistem Pendidikan Nasional yaitu Pendidikan Jasmani, Olahraga dan Kesehatan (Penjasorkes). Pembelajaran ini merupakan pembelajaran yang kompleks mengembangkan pribadi anak seutuhnya yang meliputi pengetahuan, perilaku hidup dan karakter yang baik. Lingkungan belajar diatur secara terstruktur untuk meningkatkan pertumbuhan dan perkembangan seluruh ranah jasmani, psikomotor, kognitif, dan afektif setiap siswa.

Akan tetapi berdasarkan catatan lapangan yang dilakukan oleh peneliti bahwa guru Penjasorkes khususnya di daerah pedesaan masih belum sepenuhnya memahami dan kesulitan dalam implementasi pelaksanaan pembelajaran Penjasorkes. Guru pada umumnya masih menyamakan persepsi antara pendidikan jasmani dengan olahraga.

Dengan adanya permasalahan tersebut, peneliti akan mengevaluasi Pembelajaran Penjasorkes di seluruh SMP Negeri di Kecamatan Ampelgading Kabupaten Malang dengan pendekatan 
model CIPP (context, input, process, product).

Evaluasi difokuskan pada suatu kegiatan dalam satu unit tertentu. Kegiatan tersebut dapat berupa program, proses atau hasil kerja, sedangkan yang diteliti dapat berupa tempat, organisasi ataupun lembaga. Sedangkan program merupakan sebuah sistem, yang bukan dilakukan hanya sekali tetapi secara berkesinambungan.

Winarno (2004:1) mendefinisikan bahwa evaluasi merupakan suatu proses yang sistematis untuk menentukan nilai berdasarkan data yang dikumpulkan melalui pengukuran. Arikunto (2014:2) mendefinisikan evaluasi merupakan kegiatan untuk mengumpulkan informasi tentang bekerjanya sesuatu, yang selanjutnya informasi tersebut digunakan untuk menentukan alternatif yang tepat dalam mengambil sebuah keputusan. Berdasarkan beberapa pendapat diatas dapat disimpulkan bahwa evaluasi adalah upaya menentukan nilai berdasarkan data yang diperoleh dari hasil pengukuran guna menyediakan informasi untuk disampaikan kepada pengambilan keputusan tentang efektifitas program yang sedang atau telah dilakukan.

Model evaluasi yang digunakan dalam penelitian ini yaitu model evaluasi CIPP. Model ini digunakan karena bersifat komprehensif yang mencakup kebijakan, masukan, proses dan produk atau hasil. Model CIPP terdiri dari empat komponen yaitu:

\section{Evaluasi Context}

Arikunto (2014:29) berpendapat evaluasi context adalah upaya untuk menggambarkan dan merinci lingkungan, kebutuhan yang tidak terpenuhi, populasi dan sampel yang dilayani, serta tujuan proyek. Sedangkan Widoyoko (2012:15) mengatakan bahwa evaluasi pembelajaran pada variabel context menekankan pada karakteristik peserta didik, kelengkapan, keadaan sarana dan prasarana, kurikulum, persiapan guru serta keadaan lingkungan dimana pembelajaran berlangsung. Dari penjelasan diatas dapat disimpulkan bahwa evaluasi context lebih cenderung mengevaluasi tentang kebutuhan, tujuan yang mudah atau sulit dicapai dalam evaluasi program.

\section{Evaluasi Process}

Arikunto (2014:32) evaluasi mengatakan bahwa pada variabel proses merujuk pada apa kegiatan yang dilakukan program, siapa yang ditunjuk sebagai penanggung jawab, dan kapan kegiatan akan selesai. Maka dapat dikatakan bahwa cakupan dari evaluasi proses yaitu untuk mengetahui atau mengukur apakah terjadi penyimpangan dari yang direncanakan.

\section{Evaluasi Product atau hasil}

Widoyoko (2014:12) mengatakan bahwa dalam variabel product evaluasi pembelajaran merupakan upaya untuk melakukan pengukuran terhadap hasil belajar siswa. Dari Pendapat tersebut dapat dikatakan bahwa evaluasi produk atau hasil adalah evaluasi yang dilakukan untuk mengambil keputusan tentang kinerja yang telah dilakukan mulai dari awal program sampai dengan akhir program.

\section{Pembelajaran Pendidikan Jasmani, Olahraga, dan Kesehatan}

Samsudin (2013:146) mendefinisikan Pendidikan Jasmani merupakan suatu proses pembelajaran melalui aktivitas jasmani yang di desain untuk meningkatkan kebugaran jasmani, mengembangkan keterampilan mototrik, pengetahuan dan perilaku hidup sehat dan aktif, sportif, dan kecerdasan emosi.

Berdasarkan pengertian pendidikan jasmani dari beberapa ahli diatas, dapat ditarik kesimpulan bahwa pendidikan jasmani merupakan usaha yang dilakukan secara sukarela, sadar dan intensif untuk meningkatkan keterampilan aspek afektif, kognitif, dan psikomotorik.

\section{METODE}

Secara umum metode penelitian yang dipergunakan dalam evaluasi dapat dikelompokkan menjadi metode kuantitatif, metode kualitatif, dan metode campuran. Pada penelitian evaluasi ini menggunakan metode campuran antara kualitatif dan kuantitatif. Ada beberapa pertimbangan mengapa harus menggunakan metode penelitian campuran antara lain pertimbangan teoritis dan pertimbangan praktis. Pertimbangan teoritis berarti berkaitan 
dengan data yang diperlukan untuk mencapai tujuan evaluasi sedangkan pertimbangan praktis berhubungan dengan waktu, tenaga, dan biaya. Selain itu, penggunaan metode campuran akan menghasilkan hasil yang lebih relevan. Karena metode kualitatif memungkinkan evaluator untuk meneliti objek evaluasi secara mendalam dan rinci akan tetapi hanya terbatas dari segi jumlah responden. Sebaliknya, keuntungan menggunakan metode kuantitatif yaitu dapat menjaring data yang banyak jumlahnya dan dapat disajikan dalam bentuk angka sehingga mudah dianalisis.

Data yang yang diperoleh dalam penelitian ini adalah data primer dan data skunder. Data primer diperoleh dari wawancara dan angket siswa, sedangkan data skunder diperoleh dari dokumen yang relevan dengan masalah yang diteliti. Analisis data kualitatif dibagi menjadi dua yaitu analisis data sebelum dilapangan dan analisis selama di lapangan yang dapat digambarkan sebagai berikut:

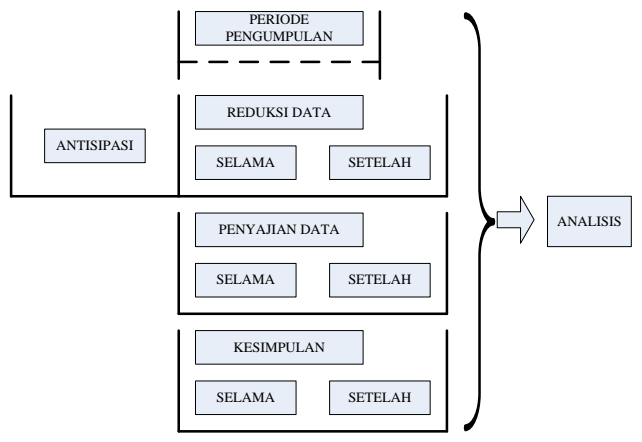

Gambar 1 Analisis Data Kualitatif (Sugiyono, 2011)

Berdasarkan komponen dalam analisis data, dalam menganalisis data kualitatif harus dilakukan dalam beberapa tahap yaitu reduksi data (data reduction), pemaparan data (data display) dan kesimpulan data (data conclusion).

Sedangkan data kuantitatif dianalisis menggunakan analisis statistik deskriptif persentase. Adapun rumusnya adalah sebagai berikut:

$$
\begin{array}{lll} 
& & \mathbf{P}=\frac{\mathbf{F}}{\mathbf{N}} \times 100 \% \\
\mathrm{P} & : & \text { Persentase } \\
\mathrm{F} & : & \text { Jumlah skor yang dicari dari } \\
\mathrm{N} & : \quad \begin{array}{l}
\text { seluruh responden } \\
\text { Jumlah skor maksimal dari }
\end{array}
\end{array}
$$

\section{seluruh responden}

Data yang terkumpul akan dipisahkan sesuai klasifikasinya, data yang berupa angka-angka akan tergolong data kuantitatif dan data yang berupa kata atau kalimat tergolong data kualitatif. Data kuantitatif akan dilakukan dengan kuesioner menggunakan skala likert dan dikotomi "ya" dan "tidak" dan diperkuat dengan jawaban terbuka dari responden yang akan ditafsirkan dalam persentase. Hasil analisis kedua skala tersebut akan diklasifikasikan sebagai berikut:

Tabel 1. Kriteria Persentase

\begin{tabular}{ccc}
\hline No & Rentangan Persentase & Kriteria \\
\hline 1 & $81 \%-100 \%$ & Baik sekali \\
2 & $61 \%-80 \%$ & Baik \\
3 & $41 \%-60 \%$ & Cukup \\
4 & $21 \%-40 \%$ & Kurang \\
& $<21 \%$ & Kurang Baik \\
\hline
\end{tabular}

HASIL

Variabel Context

Secara evaluatif hasil variabel context keseluruhan SMPN 1 Ampelgading memperoleh persentase $88 \%$ dengan kriteria baik sekali, SMPN 2 Ampelgading memperoleh persentase $83 \%$ dengan kriteria baik sekali, SMPN 3 Ampelgading memperoleh persentase $88 \%$ dengan kriteria baik sekali, SMPN 4 Ampelgading memperoleh persentase $66 \%$ dengan kriteria baik, dan SMPN 5 Ampelgading memperoleh persentase $79 \%$ dengan kriteria baik.

Hal ini menunjukkan bahwa kelima guru SMP tersebut telah memahami kebutuhan-kebutuhan dalam mengajar seperti perangkat pembelajaran. Selain itu, guru juga memahami tujuan pembelajaran pada pendidikan jasmani, olahraga, dan kesehatan (penjaskes).

\section{Variabel Input}

Secara evaluatif hasil variabel context keseluruhan SMPN 1 Ampelgading memperoleh persentase $60 \%$ dengan kriteria cukup, SMPN 2 Ampelgading memperoleh persentase $72 \%$ dengan kriteria baik, SMPN 3 Ampelgading memperoleh persentase $62 \%$ dengan kriteria baik, SMPN 4 Ampelgading memperoleh persentase $69 \%$ dengan kriteria 
baik, dan SMPN 5 Ampelgading memperoleh persentase $71 \%$ dengan kriteria baik.

Input guru maupun input siswa berperan sangat penting terhadap ketercapaian tujuan pembelajaran. Dengan guru yang sesuai dengan kompetensi bidangnya maka proses pembelajaran akan dapat terlaksana dengan baik atau setidaknya apabila belum seluruhnya tercapai, kesalahan-kesalahan dapat diminimalisir dan diperbaiki.

Bagi siswa yang mempunyai latar belakang dengan tingkat intelektual yang baik maka akan memudahkan siswa dalam belajar gerak, karena dalam pendidikan jasmani aspek keterampilan motorik sangat diperlukan. Secara evaluatif hasil variabel input untuk SMP Negeri 1 memperoleh 60\% yang dengan kriteria cukup baik, SMP Negeri 2 memperoleh $72 \%$ dengan kriteria baik, SMP Negeri 3 memperoleh $64 \%$ dengan kriteria, SMP Negeri 4 memperoleh $70 \%$ dengan kriteria baik, SMP Negeri 5 memperoleh $72 \%$ dengan kriteria baik.

\section{Variabel Process}

Dalam sebuah pembelajaran yang baik peran proses merupakan hal yang penting. Dalam sebuah proses terdapat 3 tahapan yang harus selalu ada yaitu perencanaan, pelaksanaan dan evaluasi dalam mengajar. Secara evaluatif hasil variabel context untuk SMP Negeri 1 memperoleh $70 \%$ yang dengan kriteria baik, SMP Negeri 2 memperoleh $70 \%$ dengan kriteria baik, SMP Negeri 3 memperoleh $70 \%$ dengan kriteria baik, SMP Negeri 4 memperoleh $65 \%$ dengan kriteria baik, SMP Negeri 5 memperoleh $62 \%$ dengan kriteria baik.

\section{Variabel Product}

Secara evaluatif hasil variabel context untuk SMP Negeri 1 memperoleh 75\% yang dengan kriteria baik, SMP Negeri 2 memperoleh $67.5 \%$ dengan kriteria baik, SMP Negeri 3 memperoleh $75 \%$ dengan kriteria baik, SMP Negeri 4 memperoleh $60 \%$ dengan kriteria cukup, SMP Negeri 5 memperoleh $57.5 \%$ dengan kriteria cukup.

\section{Variabel Keseluruhan CIPP}

Secara keseluruhan hasil persentase variabel CIPP pada evaluasi program pembelajaran pendidikan jasmani kelas IX di SMP Negeri seluruh Ampelgading Malang adalah baik. Dengan rincian SMP Negeri 1 mendapat $70 \%$, SMP Negeri 2 mendapat $76 \%$, SMP Negeri 3 mendapat $73 \%$ yang kesemuanya berpredikat baik, SMP Negeri 4 mendapat $64 \%$ yang apabila diakumulasikan berpredikat cukup baik, SMP Negeri 5 mendapat $62 \%$ yang apabila diakumulasikan berpredikat cukup baik.

\section{PEMBAHASAN \\ Variabel Context}

Berdasarkan hasil dari angket berupa persentase juga diperkuat data wawancara berhubungan dengan kebutuhan dan tujuan pembelajaran penjaskes yaitu kebutuhan utama yang harus dipenuhi dalam pembelajaran yaitu kebutuhan teknis dan nonteknis. Kebutuhan teknis meliputi perangkat pembelajaran sebagai pedoman dalam pembelajaran dan sarana prasarana sedangkan kebutuhan nonteknis meliputi persiapan mental, psikologis peserta didik dan segala kemungkinan yang akan terjadi pada pembelajaran, misalnya gangguan alam, penanganan siswa yang bermasalah, dll.

\section{Variabel Input}

Berdasarkan hasil dari angket yang berupa persentase juga diperkuat data wawancara yang berhubungan dengan kondisi awal siswa dan faktor yang mempengaruhi pembelajaran yang berkesimpulan bahwa kondisi awal siswa mempunyai pengaruh terhadap tujuan pembelajaran karena sangat berperan aktif dalam mempengaruhi karena siswa yang baik dari segi intelektual, sosial, dan emosional akan mempermudah guru dalam menyampaikan materi atau mengajar. Selain itu kondisi awal siswa juga dipengaruhi oleh pendidik. Bukan hanya siswa,guru juga dituntut untuk memperhatikan aspek psikologis siswa khususnya di lapangan. Oleh karena itu, guru harus mempunyai kompetensi yang jelas. Maksudnya, guru mempunyai kompetensi lulusan pendidikan jasmani dan kesehatan karena guru yang 
tidak sesuai bidangnya maka akan kesulitan khususnya dalam pengelolaan kelas, skill dan mental dalam mengajar.

\section{Variabel Process}

Dari hasil pembahasan variabel process di atas dan hasil wawancara terjadi sebuah kesesuaian dalam hal tercapainya target yang dinginkan yaitu tentang rencana dalam pembelajaran yang tidak dapat sepenuhnya dapat sesuai. Ini disebabkan karena kondisi dan situasi dalam belajar misalnya alokasi waktu, kegiatan sekolah, dan cuaca. Sedangkan sarana dan prasarana tidak boleh dijadikan alasan untuk tidak melakukan pembelajaran yang menyenangkan karena dengan memanfaatkan sarpras yang dimodifikasi siswa akan lebih tertarik, menantang dan menyenangkan. Hal yang harus diperhatikan yaitu siswa mempunyai kesempatan untuk mengeksploitasi gerak secara bebas meskipun terkendala sarana dan prasarana. Berhubungan dengan hambatan yang ditemukan dalam pembelajaran yaitu berhubungan dengan tuntutan nilai akademik yang baik, motivasi belajar siswa, cuaca, dan sarana prasarana.

\section{Variabel Product}

Berdasarkan hasil yang ingin dicapai dalam pembelajaran yaitu tercapainya aspek pembelajaran yaitu afektif, kognitif, psikomotor dan fisik. Hasil penelitian menunjukkan bahwa keempat aspek tersebut tercapai dengan baik. Hal ini dibuktikan dengan hasil belajar siswa yang baik.

\section{KESIMPULAN}

Berdasarkan pembahasan dapat dihasilkan beberapa keputusan sebagai berikut: Dalam context evaluasi pembelajaran pendidikan jasmani, olahraga, dan kesehatan di SMP Negeri se-Ampelgading Malang yang berhubungan dengan kebutuhan dan tujuan pembelajaran memperoleh kriteria baik; Dalam input evaluasi program pembelajaran pendidikan jasmani, olahraga dan kesehatan di SMP Negeri se-Ampelgading Malang yang berhubungan sumber daya manusia, sarana dan prasarana memperoleh kriteria baik; Dalam process evaluasi program pembelajaran pendidikan jasmani, olahraga, dan kesehatan di SMP Negeri seAmpelgading Malang yang berhubungan dengan perencanaan, pelaksanaan, dan evaluasi pembelajaran memperoleh kriteria baik; Dalam product evaluasi program pembelajaran pendidikan jasmani, olahraga dan kesehatan di SMP Negeri seAmpelgading Malang yang berhubungan dengan hasil belajar siswa (afektif, psikomotor, kognitif, psikomotor) memperoleh kriteria baik.

Maka dapat diputuskan bahwa evaluasi program pembelajaran pendidikan jasmani, olahraga dan kesehatan di SMP Negeri se-Ampelgading Malang secara keseluruhan dengan kriteria baik akan tetapi ada banyak hal yang harus diperbaiki (rekomendasi)

\section{Rekomendasi}

Rekomendasi ini digunakan untuk memperbaiki konsep dan rumusan program untuk memperbaiki implementasi pembelajaran. rekomendasi ini mempertimbangkan kelayakan sesuai dengan kemampuan atau sumber yang dimiliki sekolah. Adapun penjabarannya adalah sebagai berikut :

\section{SMP Negeri 1 Ampelgading}

a. Perlu ditingkatkan motivasi belajar siswa dalam mengikuti pelajaran pendidikan jasmani, olahraga dan kesehatan

b. Diharapkan sarana dan prasarana terutama kondisi lapangan harus diperbaiki untuk safety siswa

c. Perlunya pengadaan buku referensi tentang pendidikan jasmani dan olahraga untuk sumber belajar siswa

d. Diharapkan metode mengajar guru bervariatif agar siswa tidak merasa jenuh

e. Memperhatikan kemampuan siswa untuk berfikir secara kritis melalui tugas pendidikan jasmani

f. Memperhatikan safety dalam proses pembelajaran

g. Memfasilitasi peserta untuk mengeksplorasi gerakan secara maksimal 


\section{SMP Negeri 2 Ampelgading}

a. Perlunya mengembangkan pengetahuan siswa secara umum serta kesadaran baik dalam kelompok maupun pribadi

b. Motivasi siswa yang kurang dalam mengikuti pembelajaran, oleh karena itu guru diharapkan memberi feedback dalam pembelajaran agar siswa lebih bersemangat

c. Modifikasi alat yang masih kurang

\section{SMPN 3 Ampelgading}

a. Referensi buku tentang penjas yang masih kurang

b. Perlunya pengelolaan kelas yang lebih sistematis

c. Pelunya perubahan persepsi guru yang terkadang masih menyamakan antara pendidikan jasmani dengan olahraga

\section{SMPN 4 Ampelgading}

a. Perlunya memaksimalkan sarana dan prasarana yang ada, jika sarana dan prasarana belum memenuhi kelayakan maka guru dapat memodifikasi alat yang serupa tapi tidak mengurangi hakikat gerak pada materi yang akan diajarkan

b. Perlunya peningkatan motivasi belajar siswa

c. Peningkatan kompetensi professional guru yang berhubungan dengan perencanaan, pelaksanaan, dan evaluasi

d. Berhubungan dengan hasil belajar siswa, perlu ditingkatkan klasifikasi dan kategori tentang pengetahuan dasar mengenai teori

e. Perlu ditingkatkan kognisi secara umum serta kesadaran dan pengetahuan tentang kognisi diri sendiri

f. Perlunya partisipasi aktif dalam peserta didik dalam pembelajaran

\section{SMPN 5 Ampelgading}

a. Perlunya pembenahan sarana dan prasarana pendidikan jasmani dan kesehatan

b. Perlunya kelengkapan perangkat pembelajaran

c. Diharapkan adanya referensi pembelajaran untuk memudahkan siswa dalam belajar

d. Diharapkan melengkapi kelengkapan perangkat mengajar e. Perlunya pembelajaran yang inovatif agar tidak monoton

f. Diharapkan guru memperhatikan pengetahuan (kognitif) yang berhubungan dengan pengetahuan dasar dalam belajar gerak

\section{DAFTAR PUSTAKA}

Arikunto, Suharsimi. Evaluasi Program Pendidikan. Jakarta: Bumi Aksara, 2014.

Samsudin. Kurikulum Pendidikan Jasmani Olahraga dan Kesehatan 2013. Jakarta: Universitas Negeri Jakarta, 2013.

Sugiyono. Metode Penelitian Kuantitatif, Kualitatif dan $R$ \& $D$. Bandung: Alfabeta, 2013.

Sukmadinata, Nana S. Metode Penelitian Pendidikan. Bandung: Remaja Rosdakarya, 2005.

Undang-undang Nomor 20 Tahun 2003. Tentang Sisdiknas dan Peraturan. Bandung: Citra Umbara

Widoyoko, Eko Putro. Evaluasi dalam Pembelajaran. Jogjakarta: Pustaka Pelajar, 2012.

Winarno, ME. Evaluasi dalam Pendidikan Jasmani dan Olahraga. Jakarta: Center For Human Capacity Development, 2004. 